\title{
EFEKTIVITAS SENAM HAMIL TERHADAP NYERI PUNGGUNG IBU HAMIL TRIMESTER III
}

\author{
Ranny Septiani ${ }^{*}$, Islamiyati ${ }^{2}$ \\ 1 Poltekkes Tanjungkarang \\ 2 Poltekkes Tanjungkarang
}

\section{Corresponding author:}

Ranny Septiani

Poltekkes Tanjung Karang

Email: Rannyseptiani@poltekkes-tjk.ac.id

\section{Article Info:}

Dikirim: 27 Agustus 2021

Ditinjau: 18 September 2021

Diterima: 08 November 2021

DOI:

https://doi.org/10.33475/jikmh.v7i2.21

\begin{abstract}
Back pain is one of the most common complaints experienced by pregnant women in the third trimester of pregnancy. $80 \%$ of 172 pregnant women in the third trimester of pregnancy experience back pain. One way to deal with back pain is to do pregnancy exercises. There are various types of pregnancy exercise, this study uses pregnancy exercise according to Manuaba. The purpose of this study was to study the effect of pregnancy exercise according to Manuaba on back pain in third trimester pregnant women in Metro City. The design of this research is quasi-experimental research with a single group approach. The population in this study were all third trimester pregnant women at the Metro City Public Health Center. The sampling technique was accidental sampling with a sample of third trimester pregnant women with complaints of back pain. Data analysis in this study used univariate analysis with percentage frequency analysis and bivariate analysis with $t$-test. The results of this study indicate that there are differences in back pain before and after pregnancy exercise according to Manuaba with an average difference of 3.06 with $\rho$-Value $=0.000<\alpha$ : 0.05 . In conclusion, according to Manuaba, there is an effect of pregnancy exercise on back pain in pregnant women. This result is expected to be a source of reference for health workers to do pregnancy exercise according to Manuaba for pregnant women to reduce back pain in pregnant women..
\end{abstract}

Keywords: Back Pain : Pragnancy : Exercises.

\begin{abstract}
Abstrak
Nyeri punggung merupakan salah satu keluhan paling umum yang dialami ibu hamil pada trimester ketiga kehamilan. $80 \%$ dari $172 \mathrm{ibu}$ hamil pada trimester ketiga kehamilan mengalami sakit punggung. Salah satu cara mengatasi sakit punggung adalah dengan melakukan senam hamil. Ada berbagai macam jenis senam kehamilan, penelitian ini menggunakan senam kehamilan menurut Manuaba. Tujuan penelitian ini adalah untuk mempelajari pengaruh senam hamil menurut Manuaba terhadap nyeri punggung pada ibu hamil trimester III di Kota Metro. Desain penelitian ini adalah penelitian eksperimental semu dengan pendekatan kelompok tunggal. Populasi dalam penelitian ini adalah seluruh ibu hamil trimester III di Puskesmas Kota Metro. Teknik pengambilan sampel adalah accidental sampling engan sampel ibu hamil trimester III dengan keluhan nyeri punggung. Analisis data dalam penelitian ini menggunakan analisis univariat dengan analisis persentase frekuensi dan bivariat dengan uji-t. Hasil penelitian ini menunjukkan bahwa terdapat perbedaan nyeri punggung sebelum dan sesudah senam hamil menurut Manuaba dengan selisih rata-rata 3,06 dengan $\rho$-Value $=0,000<\alpha: 0,05$. Kesimpulannya, ada efek senam hamil menurut Manuaba, terhadap nyeri punggung pada ibu hamil. Hasil ini diharapkan dapat menjadi sumber rujukan bagi petugas kesehatan untuk melakukan senam hamil menurut Manuaba kepada ibu hamil untuk mengurangi sakit punggung pada ibu hamil.
\end{abstract}

Kata Kunci : Nyeri Punggung; Hamil; Senam Hamil 


\section{PENDAHULUAN}

Kehamilan membawa begitu banyak perubahan pada tubuh seorang wanita, para wanita mengalami berbagai macam ketidaknyamanan selama kehamilan, salah satu ketidaknyamanan yang sering timbul adalah nyeri punggung. Nyeri punggung lazim terjadi pada kehamilan dengan insiden yang dilaporkan bervariasi dari kira-kira 50\%.

Nyeri punggung bawah (NPB) akibat kehamilan merupakan sindroma klinis yang ditandai dengan gejala utama tidak enak di daerah tubuh bagian belakang dari rusuk terakhir atau Vertebra Thoracal 12 sampai bagian pantat atau anus dikarenakan pengaruh hormon yang menimbulkan gangguan pada substansi dasar bagian penyangga dan jaringan penghubung (connective tissue) sehingga mengakibatkan menurunnya elastisitas dan fleksibilitas otot. (Kisner et.al.,2017).

Nyeri punggung saat kehamilan dapat juga disebabkan oleh faktor mekanika yang mempengaruhi kelengkungan tulang belakang oleh perubahan sikap dan penambahan beban pada saat ibu hamil (Kisner et.al.,2017).

Di Amerika, Inggris, Swedia dan Norwegia terlaporkan $70-86 \%$ wanita hamil mengalami nyeri punggung bagian bawah (Gutke, 2018). Pada usia kehamilan 14 22 minggu, sekitar $62 \%$ wanita hamil yang melaporkan kejadian nyeri punggung bawah (Brayshaw, 2008:18).

Faktor predisposisi nyeri punggung meliputi pertumbuhan uterus yang menyebabkan perubahan postur, penambahan berat badan, pengaruh hormon relaksin terhadap ligamen, riwayat nyeri punggung terdahulu, paritas dan aktivitas. Pertumbuhan uterus yang sejalan dengan perkembangan kehamilan mengakibatkan teregangnya ligamen penopang yang biasanya dirasakan ibu sebagai spasme menusuk yang sangat nyeri yang disebut dengan nyeri ligamen. Hal inilah yang menyebabkan nyeri punggung. Sejalan dengan bertambahnya berat badan secara bertahan selama kehamilan mengubah postur tubuh sehingga pusat gravitasi tubuh bergeser ke depan. Ada kecenderungan bagi otot punggung yang memendek jika otot abdomen meregang sehingga dapat menyebabkan ketidakseimbangan otot disekitar pelvis dan tegangan tambahan dapat dirasakan diatas ligamen tersebut. Oleh sebab itu perlunya latihan otot abdomen yaitu melalui senam hamil (Fraser, 2009:228).

Nyeri punggung selama kehamilan harus mendapatkan penanganan serius karena dampak yang dapat terjadi bila nyeri punggung pada ibu hamil tidak tertangani adalah terganggunya rasa aman dan nyaman, terganggunya aktivitas selama masa kehamilan, meningkatkan kecenderungan nyeri pungung

postpartum dan nyeri punggung kronis yang akan lebih sulit untuk diobati atau disembuhkan.. Dalam Masa kehamilan dampak yang paling buruk adalah nyeri punggung dapat mempengaruhi sisi psikis ibu sehingga ibu lebih mudah menjadi stress.

Upaya yang dapat dilakukan adalah memberikan pendidikan kesehatan tentang pencegahan dan penanganan nyeri punggung pada ibu hamil yaitu senam hamil (Frezer, 2009).

Telah banyak penelitian tentang pengaruh senam hamil terhadap nyeri punggung ibu hamil trimester ketiga dengan menerapkan gerakan-gerakan senam yang bervariasi. Dalam penelitian ini peneliti menggunakan gerakan-gerakan beracuan pada buku Ilmu kebidanan, penyakit kandungan \& keluarga berencana untuk pendidikan bidan karangan IBG Manuaba. Dalam bukunya, Manuaba menuliskan bahwa melalui senam hamil, diperoleh keadaan prima dengan melatih dan mempertahankan kekuatan otot dinding perut, otot dasar panggul serta jaringan penyangganya untuk berfungsi saat persalinan berlangsung. Senam juga melemaskan persendian yang berhubungan dengan persalinan, dapat memperbaiki kedudukan janin, mengurangi ketegangan dan meningkatkan kesegaran rohani dan jasmani ibu hamil. (Manuaba,2012). Menurut hasil prasurvey peneliti di salah satu Puskesmas di Wilayah kerja Kota 
Metro, dari 15 ibu hamil trimester III, 80\% diantaranya mengalami nyeri punggung dan 20\% menyatakan tidak mengalami nyeri punggung. 25\% (3 orang) responden yang mengatakan tidak mengalami nyeri punggung, menyatakan bahwa mereka rutin melakukan senam hamil, sedangkan 50\% (6 orang) dari 12 orang responden yang mengalami nyeri punggung mengatakan bahwa mereka tidak teratur melakukan senam hamil dan bahkan tidak melakukan senam hamil sama sekali, sedangkan 25\% lainnya (3 orang) mengatakan mereka mengetahui tentang senam hamil tetapi tidak melakukan senam hamil. Tujuan Penelitian ini adalah untuk mengetahui efektifitas senam hamil menurut Manuaba terhadap nyeri punggung pada ibu hamil trimester III.

\section{METODE}

Rancangan penelitian ini adalah quasi eksperimen dengan menggunakan pendekatan one grup pre-post test. Populasi dalam penelitian ini adalah seluruh ibu hamil trimester III di Puskesmas Wilayah Kerja Kota Metro. Teknik pengambilan sampel pada penelitian ini adalah accidental sampling. Jumlah sampel dalam penelitian ini adalah 46 orang ibu hamil. Variabel dalam penelitian ini variabel independen yang digunakan adalah senam hamil menurut Manuaba dan variabel dependennya nyeri punggung. Instrumen yang digunakan berupa daftar tilik senam hamil menurut Manuaba dengan menggunakan lembar observasi berupa checklist pelaksanaan senam hamil. Teknik pengumpulan data dimulai dengan memilih sampel/responden meminta kesediaan ibu hamil untuk menjadi responden, melakukan demonstrasi senam hamil yang kemudian diikuti seluruh responden. Membekali ibu hamil dengan video senam hamil dan menyarankan ibu hamil untuk melakukan senam hamil sesuai video dan demonstrasi yang dilakukan peneliti. Senam hamil dilakukan sebanyak 3 sampai 5 kali dalam seminggu dan setiap pelaksanaannya diobservasi. Pengukuran nyeri punggung dilakukan pada sebelum responden mengikuti senam hamil dan 1 bulan setelah responden melakukan senam hamil. Pelaksanaan penelitian melibatkan peneliti sebagai pelaksana penelitian pengambilan data awal dan akhir responden, peneliti juga melakukan demonstrasi dan diskusi pada saat responden diajarkan senam hamil menurut Manuaba. Peneliti juga dibantu oleh enumerator sebagai observer pelaksaaan senam hamil yang dilakukan responden. Data hasil dianalisis dengan bantuan komputerisasi dengan anlisis univariat dan melakukan analisis bivariate dengan menggunakan uji beda hasil nyeri punggung sebelum dan sesudah senam hamil.

\section{HASIL DAN PEMBAHASAN}

Berdasarkan data penelitian yang telah dilakukan analisis yaitu analisis univariat didapat hasil berupa:

Tabel 1. Karakteristik Responden

\begin{tabular}{lcc}
\hline \multicolumn{1}{c}{ Variabel } & $\begin{array}{c}\text { Jumlah } \\
\text { (n) }\end{array}$ & $\begin{array}{c}\text { Prosentase } \\
\text { (\%) }\end{array}$ \\
\hline Umur & & \\
$<20 />35$ tahun & 8 & 17.4 \\
$20-35$ tahun & 38 & 82,6 \\
Paritas & & \\
1 & 19 & 41.3 \\
$2-3$ & 24 & 52.2 \\
$\geq 4$ & 3 & 6.5 \\
\hline \multicolumn{1}{c}{$\quad$ Variabel } & Jumlah & Prosentase \\
& (n) & (\%) \\
Pendidikan & & \\
Dasar & 3 & 6.5 \\
Menengah & 28 & 60.9 \\
Tinggi & 15 & 32.6 \\
Pekerjaan & & \\
Bekerja & 12 & 46.1 \\
Tidak Bekerja & 34 & 73.9 \\
Pengalaman & & \\
Nyeri Punggung & & 45.7 \\
Pernah & 21 & 54.3 \\
Tidak Pernah & 25 &
\end{tabular}

Berdasarkan tabel di atas maka diketahui bahwa responden yang terbanyak adalah yang mempunyai umur reproduktif sehat $(20-35$ tahun $)$ pada kelompok ibu hamil yang melakukan senam Manuaba sebanyak 38 
orang $(82,6 \%)$. jumlah paritas terbanyak adalah kehamilan $2-3$ yaitu 24 orang $(52,2 \%)$ pada kelompok ibu hamil yang melakukan senam Manuaba. jumlah terbanyak responden berdasarkan latar belakang pendidikan menengah (SMP/SMA) pada kelompok ibu hamil yang melakukan senam hamil Manuaba sebanyak 28 orang $(60,9 \%)$. Berdasarkan latar belakang pekerjaan responden pada responden adalah ibu hamil yang tidak bekerja / IRT yaitu sebesar 34 orang (73,9\%). Tabel di atas juga menunjukkan pada kelompok ibu hamil yang melakukan senam hamil menurut Manuaba terbanyak adalah yang tidak mempunyai riwayat nyeri punggung sebelumnya yaitu sebesar 25 orang $(54,3 \%)$.

Tabel 2. Distribusi Skala Nyeri Punggung Sebelum dan Sesudah Senam Hamil Menurut Manuaba

\begin{tabular}{lcc}
\hline Skala Nyeri Punggung & $\begin{array}{c}\text { Jumlah } \\
\text { (n) }\end{array}$ & $\begin{array}{c}\text { Prosentase } \\
\text { (\%) }\end{array}$ \\
\hline Sebelum Senam Hamil & & \\
Tidak Nyeri (0) & 0 & 0 \\
Nyeri Ringan (1-3) & 28 & 60.9 \\
Nyeri Sedang (4-6) & 1 & 34.8 \\
Nyeri Berat (7-9) & 2 & 4.3 \\
Nyeri Sangat Berat (10) & 0 & 0
\end{tabular}

\begin{tabular}{lcc}
\hline Skala Nyeri Punggung & $\begin{array}{c}\text { Jumlah } \\
(\mathbf{n})\end{array}$ & $\begin{array}{c}\text { Prosentase } \\
(\%)\end{array}$ \\
\hline Sesudah Senam Hamil & & \\
Tidak Nyeri (0) & 4 & 8.7 \\
Nyeri Ringan (1-3) & 35 & 76.1 \\
Nyeri Sedang (4-6) & 7 & 15.2 \\
Nyeri Berat (7-9) & 0 & 0 \\
Nyeri Sangat Berat (10) & 0 & 0
\end{tabular}

Berdasarkan tabel diatas maka dapat disimpulkan bahwa nyeri punggung ibu hamil sebelum senam hamil menurut Manuaba terbanyak adalah skala nyeri ringan sebanyak 28 orang $(60,9 \%)$ dan nyeri punggung ibu hamil setelah senam hamil menurut Manuaba terbanyak adalah skala nyeri ringan sebanyak 35 orang $(76,1 \%)$.

Hasil analisis data bivariat menggunakan uji beda antara skala nyeri pungung sebelum dan sesudah senam hamil menurut Manuaba didapatkan hasil :
Tabel 2. Perbedaan Skala Nyeri Sebelum dan Sesudah Senam Hamil menurut Manuaba

\begin{tabular}{ccccc}
\hline Deskripsi & Min & Max & Mean & SD \\
\hline Skala Nyeri Sebelum Intervensi & 1 & 8 & 3.52 & 1.616 \\
Skala Nyeri Sesudah Intervensi & 0 & 6 & 2.07 & 1.389 \\
\hline
\end{tabular}

Menurut tabel di atas maka diketahui rata-rata nyeri punggung sebelum senam hamil Manuaba adalah 3,52 dengan standar deviasi 1,616 dan nilai minimal 1 dan maksimal 8. Sedangkan rata-rata nyeri punggung sesudah senam adalah 2,07 dengan standar deviasi 1,389 dan nilai minimal 0 maksimal 6 . Sedangkan rata-rata selisih skala nyeri sebelum dan sesudah senam yaitu 1,45

Hasil uji statistik t-test dependen menunjukkan bahwa $\mathrm{p}$ value $=0,000<\alpha: 0,05$ yang berarti ada perbedaan pada skala nyeri punggung pada ibu hamil trimester III di Wilayah Kerja Puskesmas Kota Metro Tahun 2017 sebelum dan sesudah rutin melakukan senam hamil Manuaba.

Salah satu ketidaknyamanan yang sering dirasakan pada masa kehamilan terutama pada trimester III adalah nyeri punggung. banyak sekali faktor risiko penyebab nyeri punggung tersebut antara lain riwayat nyeri punggung sebelumnya, tidak ada bantuan pekerjaan rumah tangga hal ini ditunjukan oleh hasil penelitian Sencan S, dkk (2017) yang menyatakan prevalensi nyeri punggung terjadi $53,9 \%$ pada wanita di Turkey pada masa kehamilan Trimester III.

Salah satu cara untuk mengurangi nyeri punggung salah satunya adalah melakukan latihan fisik atau senam hamil. (Yosefa, etall, 2013). Senam hamil merupakan bentuk latihan fisik yang berguna memperkuat dan mempertahankan elastisitas otot-otot dinding perut, ligamen-ligamen, serta otot dasar panggul. Hasil penelitian Van Banten, dkk (2014) yang dimuat dalam Journal Orthopedi \& Sport Physical Therapy menunjukkan bahwa Latihan fisik atau therapy fisik 
dapat mengurangi nyeri punggung selama kehamilan. Hal ini memperkuat teori dari Manuaba (2012; 135-136) bahwa dengan senam hamil maka ibu hamil akan memperoleh keadaan prima dengan melatih dan mempertahankan kekuatan otot dinding perut, otot dasar panggul serta jaringan penyangganya yang berfungsi saat persalinan berlangsung.

Senam juga melemaskan persendian yang berhubungan dengan persalinan, dapat memperbaiki kedudukan janin, mengurangi ketegangan dan meningkatkan kepercayaan diri dalam menghadapi persalinan memperoleh pengetahuan dan kemampuan mengatur pernapasan, relaksasi dan kontraksi otot perut, otot sekat rongga badan, dan otot dasar panggul saat persalinan.

Dengan senam juga meningkatkan kemampuan mengoordinasi kekuatan kontraksi otot rahim sehingga tercapai hasil optimal menuju jalan lahir dan meningkatkan kesegaran rohani dan jasmani ibu hamil.

Hal ini juga sesuai dengan studi yang dilakukan oleh Lichayati dan Kartikasari (2011) tentang Hubungan senam hamil dengan nyeri punggung pada ibu hamil di Polindes Desa Tlanak Kecamatan Kedungpring Kabupaten Lamongan, dengan sampel 33 ibu hamil trimester II dan III, didapatkan hasil bahwa 75\% dari ibu hamil tidak pernah melakukan senam hamil menderita nyeri punggung. Sedangkan ibu hamil yang rutin sekali melakukan senam hamil 100\% tidak ada yang menderita nyeri punggung.

Sedangkan dari hasil uji beda nyeri punggung pada saat sebelum dan sesudah senam hamil Manuaba dengan $P$ value $0,000<0,05$ yang berarti senam hamil Manuaba memiliki keefektifitasan yang cukup dalam menurunkan nyeri punggung. Hal ini sesuai dengan isi senam hamil Manuaba dimana terdapat beberapa gerakan yang melibatkan otot punggung secara langsung sehingga dapat mengurangi nyeri punggung pada kehamilan.

Hal ini kemungkinan juga disebabkan karena 38 orang $(82,6 \%)$ ibu hamil di kelompok senam hamil Manuaba adalah ibu hamil di usia reproduktif yaitu usia 20-35 tahun, dimana menurut Notoatmodjo (2007) yang dikuti oleh Lichayati dkk (2011) pada usia 21- 30 tahun merupakan usia produktif dimana seorang wanita aktif dalam menerima informasi. Pada masa ini merupakan usia dewasa muda, dimana daya ingat terhadap informasi yang diterima baik langsung maupun tidak langsung akan lebih mudah diingat dan dipahami, sehingga ibu akan mempunyai pengetahuan cukup khususnya pengetahuan tentang pentingnya melakukan senam hamil selama kehamilannya.

\section{KESIMPULAN}

Dari hasil penelitian yang dilakukan di Wilayah Kerja Puskesmas Kota Metro sebanyak 46 responden ibu hamil trimester III yang mengalami nyeri punggung dapat ditarik kesimpulan ada perbedaan skala nyeri punggung sebelum dan sesudah melakukan senam hami menurut Manuaba terhadap pengurangan nyeri punggung pada ibu hamil trimester III dengan rata-rata selisih skala nyeri 1,45. Berarti senam hamil menurut manuaba efektif mengurangi nyeri punggung pada ibu hamil trimester III. Berdasarkan penelitian ini diharapkan petugas kesehatan khususnya bidan untuk dapat menerapkan metode senam hamil menurut manuaba pada ibu hamil trimester tiga yang mengalami nyeri punggung.

\section{UCAPAN TERIMA KASIH}

Ucapan Terimakasih penulis haturkan kepada pihak-pihak yang telah membantu penelitian sehingga penelitian ini dapat terlaksana dan mendapatkan hasil yang diharapkan. Terimakasih kepada Direktur Poltekkes Tanjungkarang melalui Unit Penelitian dan Pengabdian Kepada Masyarakat Poltekkes Tanjungkarang yang telah memfasilitasi kegiatan penelitian ini baik secara materil maupun Moril 


\section{DAFTAR RUJUKAN}

Brayshaw, Eileen, 2008, Senam Hamil \& Nifas: Pedoman Praktis Bidan, Jakarta, EGC, 179 hal.

Fraser, G. E., \& Poncia, H. (2009). Spontaneous renal artery aneurysm rupture: an unusual cause of abdominal pain and syncope. Emergency Medicine Journal, 26(8), 619-620

Gutke, A., Boissonnault, J., Brook, G., \& Stuge, B. (2018). The severity and impact of pelvic girdle pain and low-back pain in pregnancy: a multinational study. Journal of women's

health, 27(4), 510-517.

Kisner, C., Colby, L. A., \& Borstad, J.

(2017). Therapeutic exercise: foundations and techniques. Fa Davis.

Lichayati, Isma'ul; Kartikasari, Ratih Indah; 2011, Hubungan Senam Hamil Dengan Nyeri Punggung Pada Ibu Hamil Di Polindes Desa Tlanak Kecamatan Kedungpring Kabupaten Lamongan, Jurnal Kesehatan, Stikes Muhammadiyah Lamongan, Jawa Timur, tersedia online [15 Oktober 2016] http://stikesmuhla.ac.id

Manuaba, I. B. G. (2012). Ilmu kebidanan, penyakit kandungan \& keluarga berencana untuk pendidikan bidan. Jakarta, EGC.693 halaman.

Notoatmodjo, S. (2007). Pendidikan dan Perilaku Kesehatan, Cetakan 2. Rineka Cipta: Jakarta.

Sencan S, Ozcan-EksiEE; 2017, Pragnancy-related low back pain in Women in Turkey, available et: https://www.ncbi.nlm.nih.gov/pubmed/29042300 \{Access Nopember 20,2017)

Van Benten et al, titled "Recommendations for Physical Therapists on the Treatment of Lumbopelvic Pain During Pregnancy: A Systematic Review," $J$ Orthop Sports Phys Ther 2014;44(7):464-473. Epub 10 May 2014. doi:10.2519/jospt.2014.509

Yosefa, Febrina; Misrawati; Hasneli, Yesi; 2013, Efektifitas Senam Hamil Terhadap Penurunan Nyeri Punggung Pada Ibu Hamil, Jurnal Kesehatan, Universitas Riau, Riau. Tersedia online [15 Oktober 2016] http://download.portalgaruda.org

Cite this article as: Septiani, R., Islamiyati,. (2021). Efektifitas Senam Hamil Terhadap Nyeri Punggung Ibu Hamil Trisemester III . Jurnal Ilmiah Media Husada. 10(2 ), 82-87. https://doi.org/10.33475/jikmh.v7i2.21 